\title{
Potential Use of Chromolaena odorata Linn. Flavonoids against Escherichia coli Induced Diarrhoea in Mice
}

\author{
Chao-Qun Shi ${ }^{1}$, Hong-Ying Lin', Jin-Qing Zheng, Fan Yang ${ }^{1}$, Kwame Ayisi Lartey ${ }^{1}$, \\ Dan-Ju Kang1, Hwa-Chian Robert Wang ${ }^{2}$, Ravi Gooneratne ${ }^{3 *}$ and Jin-Jun Chen ${ }^{1 *}$
}

${ }^{1}$ Department of Veterinary Medicine, College of Agricultural Sciences, Guangdong Ocean University, Zhanjiang, Guangdong 524088 China

${ }^{2}$ Department of Biomedical and Diagnostic Sciences, College of Veterinary Medicine, University of Tennessee, Knoxville, TN37996, USA

${ }^{3}$ Department of Wine, Food and Molecular Biosciences, Faculty of Agriculture and Life Sciences, Lincoln University, Lincoln 7647, New Zealand

Chao-Qun Shi and Hong-Ying Lin contributed equally to this work.

\begin{tabular}{|c|}
\hline \\
\hline $\begin{array}{l}\text { Flavonoids are important chemotaxonomic markers for the genus Chromolaena. Chromolaena odorata } \\
\text { Linn. (CO) is used in folklore medicines to treat gastrointestinal diseases such as diarrhoea. This study } \\
\text { examined the feasibility of total flavonoids from } C \text {. odorata }(\mathrm{TFCO}) \text { as an antibacterial agent in vitro, and } \\
\text { the mechanism of action of TFCO in combating Escherichia coli-induced diarrhoea in mice. MBC and } \\
\text { MIC values of } 0.25 \text { and } 0.125 \mathrm{~g} \text { TFCO/ml showed it was effective as an antibacterial agent against } E \text {. coli } \\
(\mathrm{CMCC} 44752) \text { in vitro. Ninety Kunming mice were randomly divided into five groups of } 18 \mathrm{mice} \text { per } \\
\text { group }(1 \mathrm{male}: 1 \mathrm{female}) \text {. The groups were control (saline), negative control }(E \text {. coli }+0 \mathrm{mg} / \mathrm{kg} \mathrm{TFCO}) \text {, } \\
\text { low dose }(E \text {. coli }+10 \mathrm{mg} / \mathrm{kg} \text { TFCO), medium dose }(E . \text { coli }+40 \mathrm{mg} / \mathrm{kg} \mathrm{TFCO}) \text {, and high dose }(E \text {. coli } \\
+160 \mathrm{mg} / \mathrm{kg}) \text {. TFCO was administered by gavage } 3 \mathrm{~h} \text { post intraperitoneal }(i . p) E \text {. coli injection. Serum } \\
\text { IgM, IgA, IgG, TGF- } \beta 1 \mathrm{mRNA} \text { expression in duodenal villi, and histopathology of duodenum were also } \\
\text { studied. TFCO significantly increased the IgA and IgG concentration }(P<0.05) \text {, reversed the intestinal } \\
\text { mucosal damage caused by } E \text {. coli, and increased the relative expression of TGF- } \beta 1 \text { mRNA. Therefore, } \\
\text { TFCO has potential to improve immune function against } E \text {. coli infection, restored the intestinal structure } \\
\text { and cured the } E \text {. coli-induced diarrhoea in mice. }\end{array}$ \\
\hline
\end{tabular}

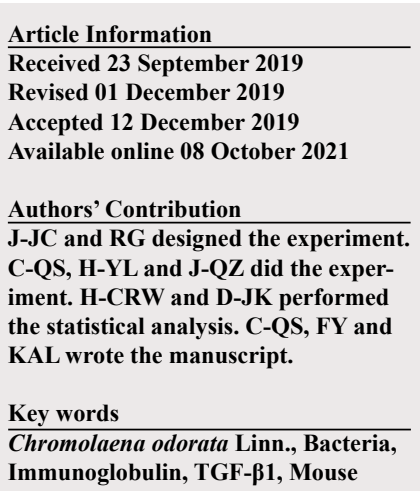

Article Information

Revised 23 September 2019

Available online 08 October 202

Authors' Contribution

$\mathrm{J}-\mathrm{JC}$ and $\mathrm{RG}$ designed the experiment. C-QS, H-YL and J-QZ did the experthe statistical analysis. C-QS, FY and KAL wrote the manuscript.

Immunoglobulin, TGF- $\beta 1$, Mouse

\section{INTRODUCTION}

$\mathrm{H}$ erbal plants in the family Asteraceae have characteristic flavonoids and phenolics which account for their pharmacological significance (Pisutthanan et al., 2006). Chromolaena odorata Linn. (formally called Eupatorium odoratum) is a common invasive herbal plant in the Asteraceae family (Tonzibo et al., 2007). It is widely distributed in the humid tropics and sub-tropics of Africa and Asia where it causes agro-ecological destructions (Tonzibo et al., 2007). C. odorata has been explored in Indian Ayuveeda, traditional Chinese medicines and African folkore medicines to prevent and control several gastrointestinal disorders including diarrhoea (Panda et al., 2010; Aba et al., 2015). Toxicological evaluations and

\footnotetext{
* Corresponding author: jjchen777@aliyun.com; Ravi. Gooneratne@lincoln.ac.nz 0030-9923/2021/0006-2269 \$ 9.00/0

Copyright 2021 Zoological Society of Pakistan
}

analytical studies have further revealed that, pyrrolizidine alkaloids levels in the leaves and stems of the herbal plant are insignificant and they can be further reduced by organic solvent extractions (Ogbonnia et al., 2010). Flavonoids obtained from ethanol and methanol extractions of herbal medicines are less toxic based on hepatotoxic, mutagenic, and cytotoxic evaluations (Ogbonnia et al., 2010; Asomugha et al., 2015). They have also been found to have broad-spectrum anti-bacteria effects against gram positive and gram negative bacteria (Omokhua et al., 2017). Infectious bacteria such as Escherichia coli cause diarrhoea which remains a major health problem in food animal's production especially swine and poultry (Gomes et al., 2016; Lin et al., 2017). E. coli -induced diarrhoea lowers production efficiency and their control also increases production cost and economic loss (Lin et al., 2017). Enterohemorrhagic Escherichia coli (EHEC) are the pathogenic subgroup of Shiga toxin (Stx)-producing E. coli. EHEC can cause non-bloody and bloody diarrhoea (Bryan et al., 2015). They multiply quickly in 
the gastrointestinal tract and cause damage to tissues and organs such gastrointestinal tract, kidneys, spleen, liver, and even death in severe cases (Börjesson et al., 2016). Synthetic antibiotics are currently the most commonly used drugs for prevention and treatment of diarrhoea in food animals. However, this has led to the development of bacterial resistance, and antibiotic residues in meats thereby posing threats to biosafety. Consumer demands for "green label" feed additives as alternatives to synthetic antibiotics is on the increase (Liu et al., 2011). They are posited to be biologically safer, environmentallyfriendly and economically cheaper compared to synthetic antibiotics (Liu et al., 2011). Phytochemicals have been used in folklore medicines and ethnoveterinary to prevent and treat several ailments. Increasing evidence supports the assertion that, flavonoids are beneficial for gastrointestinal health (Unnikrishnan et al., 2014).

Earlier studies from our laboratory using 16s RNA sequencing and Miseq amplification showed that, total flavonoids of $C$. odorata (TFCO) exerts competitive exclusions to prevent inoculation of disease-causing bacteria such as E. coli in the cecum of broiler chickens and enhances serum humoral immunity as a result (Zhang et al., 2018). In this study, total flavonoids were extracted from $C$. odorata aerial parts. The potential of the total flavonoids from $C$. odorata (TFCO) as an antibacterial agent was examined in vitro. Kunming mice were further used as a model to examine the antibacterial activity of the TFCO in combating E. coli-induced diarrhoea. Duodenal mucosal villi structure, $\operatorname{IgM}, \operatorname{IgA}$, and IgG concentrations, and a key factor in intestinal mucosal repair, TGF- $\beta 1$ expressions were also monitored to get an overall understanding of the mechanism of action of TFCO. Detection and analysis of the flavonoid compositions is however beyond the scope of this study.

\section{MATERIALS AND METHODS}

The aerial parts of young and non-flowering $C$. odorata were collected the campus of Guangdong Ocean University, Zhanjiang- China (Guangdong Province, China) in summer (June). Herbs were identified and confirmed by the Botany Department of the College of Agricultural Sciences, Guangdong Ocean University. These aerial parts were cleaned, shade-dried, pulverized, and passed through a 150-mesh sieve. The powder was preserved in a refrigerator at $4{ }^{\circ} \mathrm{C}$ until extraction. Total flavonoids were extracted by solvent- solvent extraction as described by Owoyele et al. (2008) with slight modification. Briefly, ten grams of the dried powder was dissolved in $500 \mathrm{ml} \mathrm{70 \%}$ ethanol (a solid: liquid ratio of 1:60) for 24 $\mathrm{h}$, extracted for $5 \mathrm{~h}$ at $70^{\circ} \mathrm{C}$ using an ultrasonic washing device (KQ-500DE, Kunshan Ultrasonic Instruments Co., China) and filtered. Filtrate was purified with petroleum ether (10:1) using ethyl acetate extraction. The primary purified extract was placed in an electro-thermal incubator, evaporated at $70^{\circ} \mathrm{C}$ and stored in a refrigerator at $4^{\circ} \mathrm{C} .160$ $\mathrm{mg}$ of the resulting powder material was then dissolved in $1 \mathrm{ml}$ dimethyl sulfoxide solvent (DMSO: Water, 2:4 v/v) to prepare the stock solution of $160 \mathrm{mg} / \mathrm{ml}$, then this stock was 4 -fold diluted with saline to obtain $40 \mathrm{mg} / \mathrm{ml}$, and 16fold diluted with saline to obtain $10 \mathrm{mg} / \mathrm{ml}$.

\section{Bacterial studies}

Strains of Staphylococcus aureus (ATCC 25923), Salmonella pullorum (ATCC 14028), Escherichia coli (CMCC 44752) and Bacillus subtilis (CMCC (B) 63501) were used. They were obtained from the Veterinary Medicine Department of Guangdong Ocean University. The antibacterial activity of the flavonoids of TFCO was screened using the agar disc diffusion assay. Bacterial suspensions were prepared by inoculating bacteria onto nutrient agar plate and culturing at $37^{\circ} \mathrm{C}$ for $16 \mathrm{~h}$. A single colony was inoculated into liquid broth and allowed to grow for $16 \mathrm{~h}$ at $37^{\circ} \mathrm{C}$, and the culture was diluted with liquid broth to a final concentration of $10^{7} \mathrm{CFU} / \mathrm{ml}$. $100 \mu \mathrm{l}$ of inoculum was spread on the nutrient agar plates. Sterile filter paper disc $(5 \mathrm{~mm})$ loaded with $10 \mu \mathrm{l}$ of TFCO was placed on the agar plates containing bacterial inoculum. The inoculated plates were left for $30 \mathrm{~min}$ at room temperature for diffusion of the TFCO into agar and then incubated at $37^{\circ} \mathrm{C}$ for $48 \mathrm{~h}$. Microbial inhibition was determined by measuring the diameter of the clear zone surrounding the discs; the result was recorded in millimeter $(\mathrm{mm})$. All the tests were performed in triplicate (Alshaikh and Perveen, 2017).

\section{Determination of $M I C$ and $M B C$}

Broth microdilution was performed as described by the Clinical and Laboratory Standards Institute (CLSI, 2017). To determine minimum inhibitory concentration (MIC), 2-fold serial dilutions of each antibiotic were prepared in test tubes with concentrations ranging from $0.002 \mathrm{~g} / \mathrm{ml}$ to $2 \mathrm{~g} / \mathrm{ml}$. Inoculated tubes were incubated at $37^{\circ} \mathrm{C}$ for $24 \mathrm{~h}$. All the tests were performed in triplicate. The lowest concentration of each antibacterial agent that inhibited the bacterial growth was then considered as the MIC. Minimum bactericidal concentration (MBC) was determined by culturing on agar plate. Plates were incubated at $37^{\circ} \mathrm{C}$ for $48 \mathrm{~h}$, and viable colonies were counted. The lowest concentration that killed $100 \%$ of the initial bacterial population (with no colonies on the agar) was recorded as the $\mathrm{MBC}$. 


\section{Animal studies}

Ninety Kunming mice, six-eight weeks-old with similar initial weights $(20 \pm 3 \mathrm{~g})$, were fed ad libitum with a balanced isoenergetic diet that met all the nutritional requirements. All mice received free access to water. Mice were randomly assigned into five groups of 18 mice per group i.e. control (saline), negative control (E. coli + $0 \mathrm{mg} / \mathrm{kg}$ TFCO), low dose (E. coli $+10 \mathrm{mg} / \mathrm{kg}$ TFCO), medium dose (E. coli $+40 \mathrm{mg} / \mathrm{kg}$ TFCO), and high dose (E. coli $+160 \mathrm{mg} / \mathrm{kg}) .3 \mathrm{~h}$ post intraperitoneal (i.p) E. coli $\left(3 \times 10^{8}\right.$ Escherichia coli (CMCC 44752) injection, mousemodel of diarrhoea was made and TFCO administered by gavage. Six mice ( 3 males, 3 female) from each group were euthanized on 2, 5 and $8 \mathrm{~d}$ post injection.

\section{Histopathology of duodenum}

On $8 \mathrm{~d}$, mice were euthanized and then autopsied. A portion of the duodenum cut from all animals was fixed in $10 \%$ formaldehyde overnight, dehydrated in a graded series of alcohol, and cleared in xylene prior to being embedded in paraffin. Serial $4-\mu \mathrm{m}$-thick paraffin sections were transferred to glass slides, deparaffinized and stained with hematoxylin and eosin for histopathological studies using a microscope (ECLIPSE E200, Nikon, Japan).

\section{$\operatorname{Ig} G, \operatorname{Ig} M$ and $\operatorname{Ig} A$}

Blood was collected from all mice on days 2, 5, and 8 following the dose. Individual samples were centrifuged for $3 \mathrm{~min}$ at $3000 \mathrm{r} / \mathrm{min}$, serum were separated and stored in a freezer at $-20^{\circ} \mathrm{C}$. The IgG, IgM and IgA were measured in 96-well plates, using an ELISA kit (Fanke Co., Shanghai, China) according to the manufacturer's instructions.

\section{$R N A$ extraction, primer design and real-time $P C R$}

A small piece of the duodenum from each mouse was removed soon after euthanasia, washed with saline to remove intestinal contents, labelled, frozen immediately in liquid nitrogen, and stored in a freezer at $-80^{\circ} \mathrm{C}$. A separate $30 \mathrm{mg}$ of duodenal tissue was collected and mixed with 1.5 ml Trizol (Takara Co., Otsu, Japan) to determine TGF- $\beta 1$ expression. Reverse transcription-polymerase chain reaction (PCR) assay for mRNA expression of $\beta$-actin and TGF- $\beta 1$ was carried out as described by Li et al. (2010). RNA was extracted with Trizol reagent (Takara Co. Otsu, Japan) according to the manufacturer's recommended procedure. RNA $(2 \mu \mathrm{l})$ was reverse-transcribed using an M-MuLV First Strand cDNA Synthesis Kit (Takara Co. Otsu, Japan). All primer sequences were from the Ying Wei Jie Ji Co., Shanghai, China. PCR was performed using a real time PCR Kit (Takara Co. Otsu, Japan). $10 \mu$ reaction mixture of SYBR Premix ExTaqTM II (Takara Co. Otsu, Japan) was added to $2 \mu \mathrm{l}$ cDNA template, $0.8 \mu$ f forward primer $(10 \mu \mathrm{mol} / \mathrm{l}), 0.8 \mu \mathrm{l}$ reverse primer $(10 \mu \mathrm{mol} / \mathrm{l}), 6.0$ $\mu \mathrm{l}$ sterile distilled water and $0.4 \mu \mathrm{l}$ ROX Reference Dye $(50 \times)$. Cycling conditions were: $95^{\circ} \mathrm{C}$ for $35 \mathrm{sec}$; 40 cycles of $95^{\circ} \mathrm{C}$ for $20 \mathrm{sec}, 64^{\circ} \mathrm{C}$ for $35 \mathrm{sec}$, $72^{\circ} \mathrm{C}$ for $20 \mathrm{sec}$; $60^{\circ} \mathrm{C}$ for $1 \mathrm{~min}$ and cooled to $4^{\circ} \mathrm{C}$. PCR was performed in tandem with $\beta$-actin primers as an internal control. DNA sequences are shown as below.

TGF- $\beta 1$ F: 5'-GCCCTGGATACCAACTATTGC-3', R: 5'-GCAGGAGCCACAATCATGTT-3.

$\beta$-actin: F: 5'-GTCCCGGCCAGCCAGGTCCAG-3', R: 5'-CCTAAGGCCAACCGTGAAAAGATG-3'.

The relative change in TGF- $\beta 1$ expression levels was determined from qPCR and calculated according to the 2 $-\triangle \triangle \mathrm{CT}$ method, $\triangle \mathrm{CT}=\mathrm{CT}_{\mathrm{TGF}-\beta 1}-\mathrm{CT}_{\beta \text {-actin }}$.

\section{Statistical analysis}

All statistical analyses were performed using the statistical software SPSS version 17.0. Using ANOVA method, multiple comparisons were made using the LSD method, and the results are expressed as mean \pm SD. $P<0.05$ was considered statistically significant. MIC and $\mathrm{MBC}$ for each antimicrobial agent are reported as minimum, maximum, median, and range $(95 \% \mathrm{CI})$ values.

\section{Ethical considerations}

All mice were housed in an environmentallycontrolled environment. All animal care and sacrifice were in accordance with the country standards. This research protocol was approved by the Animal Ethics Committee of Guangdong Ocean University (Approval No: NXY20160172). The guidelines of Animal Research: Reporting of In Vivo Experiment (ARRIVE) guidelines were adhered to.

\section{RESULTS}

\section{TFCO concentration}

The yield of TFCO obtained from the ethanol extraction was $18.8 \%(\mathrm{w} / \mathrm{w})$.

\section{MIC and $M B C$}

The bacteriostatic circle diameter in the four types of bacteria (Staphylococcus aureus, Salmonella pullorum, E. coli, Bacillus subtilis $)$ exposed to TFCO $(0.5 \mathrm{~g} / \mathrm{ml})$ was $>$ $11 \mathrm{~mm}$. The antibacterial effect of TFCO was highest on $S$. aureus with an inhibition zone of $19.5 \mathrm{~mm}$, and least on $E$. coli with $11 \mathrm{~mm}$ (see Table I).

The MIC and MBC for $S$. aureus were the lowest, with values of 0.0156 and $0.0313 \mathrm{~g} / \mathrm{ml}$ respectively, indicating that TFCO was highly bacteriostatic against $S$. aureus in vitro (see Table II). 
Table I. In-vitro bacteriostatic activity of Chromolaena odorata Linn. flavonoids tested at a concentration of $0.5 \mathrm{~g} / \mathrm{ml}$.

\begin{tabular}{ll}
\hline Bacteria & Bacteriostatic diameter/mm \\
\hline Escherichia coli & $11.00 \pm 0.05$ \\
Salmonella pullorum & $13.33 \pm 0.89$ \\
Staphylococcus aureus & $19.50 \pm 0.25$ \\
Bacillus subtilis & $13.67 \pm 0.22$ \\
\hline
\end{tabular}

Table II. MIC and MBC of Chromolaena odorata Linn. flavonoids in vitro.

\begin{tabular}{lll}
\hline Bacteria & $\mathbf{M I C}^{\mathrm{a}}(\mathbf{g} / \mathbf{m l})$ & $\mathbf{M B C}^{\mathrm{b}}(\mathrm{g} / \mathbf{m l})$ \\
\hline Escherichia coli & 0.1250 & 0.2500 \\
Salmonella pullorum & 0.0313 & 0.1250 \\
Staphyloccocus aureus & 0.0156 & 0.0313 \\
Bacillus subtilis & 0.0625 & 0.1250 \\
\hline
\end{tabular}

${ }^{\mathrm{a}}$ minimum inhibitory concentration $(\mathrm{g} / \mathrm{ml})$; ${ }^{\mathrm{b}}$ minimum bactericidal concentration $(\mathrm{g} / \mathrm{ml})$.

\section{Diarrhoea}

Three hours post injection, E. coli injected mice (negative control and three treatment groups) exhibited clinical changes but the saline injected mice (blank control) did not. Observed clinical changes were slight reduction in physical activity and watery diarrhoea followed by bloody diarrhoea. On day 2, all mice developed diarrhoea except mice in the blank control. On days 3,4 , and 5 , the diarrhoea incidence among $E$. coli injected (negative control and three treatment groups) mice was lowest in the high dose $(160 \mathrm{mg} / \mathrm{kg})$ TFCO group. Diarrhoea incidence for the high dose TFCO $(160 \mathrm{mg} / \mathrm{kg})$ was $58.3 \%, 25 \%$, and $8.3 \%$ for days 3, 4 and 5 respectively. On day 6 , none of the animals exhibited diarrhoea except the negative control $(E$. coli $+0 \mathrm{mg} / \mathrm{kg}$ TFCO).

\section{Duodenal villi structure}

In the blank control group, the duodenal mucosa in mice was normal, with intact intestinal villi and small intestinal glands and no obvious pathological change (Fig. 1a). The negative control (E. coli $+0 \mathrm{mg} / \mathrm{kg}$ TFCO) group showed marked duodenal mucosal damages with breakages in the intestinal villi and sparsely arranged intestinal epithelial cells (Fig. 1b). In the low dose (E. coli $+10 \mathrm{mg} / \mathrm{kg}$ TFCO) group, duodenal villi rupture and atrophy were visible (Fig. 1c). In the medium dose (E. coli $+40 \mathrm{mg} / \mathrm{kg}$ ) group, some villi exhibited swelling and sloughing off (Fig. 1d). In the high dose (E. coli $+160 \mathrm{mg} /$ $\mathrm{kg}$ group), the duodenal villi had returned to normal, with only a few occasional damaged intestinal villi (Fig. 1e).

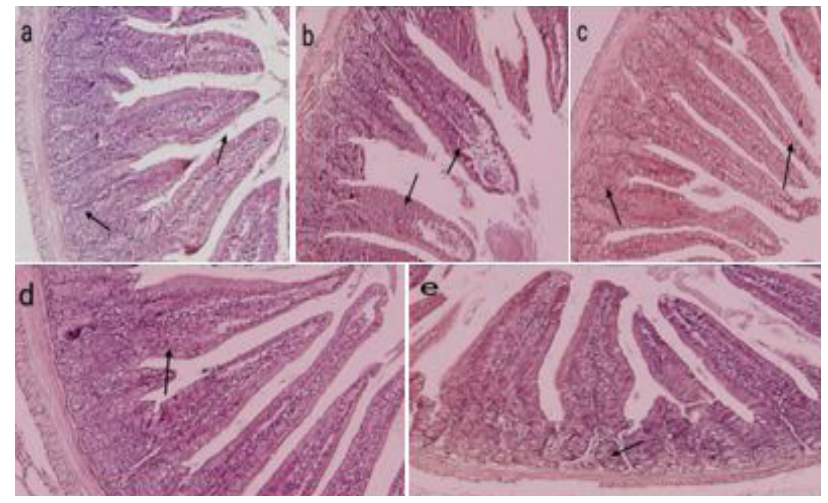

Fig. 1. Histopathology of duodenal villi (hematoxylin eosin stain, $\times 100)$ in controls and mice exposed E. coli and chromolaena odorata Linn. Flavonoids (COF).

Control group: duodenal villi and small intestinal glands are complete and clear. (b) E. coli $+0 \mathrm{mg} \mathrm{COF} / \mathrm{kg}$ group; Rupture of duodenal villi intestinal epithelial cells arranged sparsely. (c) $E$. coli $+10 \mathrm{mg} \mathrm{COF} / \mathrm{kg}$ group, duodenal villi damaged with some atrophy. (d) E. coli $+40 \mathrm{mg} \mathrm{COF} /$ $\mathrm{kg}$ group, epithelial cells of duodenal villi abscission and partially visible swelling of the intestinal villi. (e) E. coli $+160 \mathrm{mg} \mathrm{COF} / \mathrm{kg}$ group, showing normal duodenal villi. The arrows indicates duodenal villi.

\section{Relative expression of TGF- $\beta 1$ mRNA in duodenum}

On day 2 after $E$. coli infection, the relative expression of TGF- $\beta 1 \mathrm{mRNA}$ in the mice given TFCO was significantly higher than that of the blank control group $(P<0.01)$ and this was most marked in the highdose group $(P<0.05)$. At 5 days after $E$. coli infection, the relative expression of TGF- $\beta 1$ mRNA declined in all the treatment groups, but was still significantly higher than the control group $(P<0.01)$ but there was no significant difference between the TFCO treatment groups $(P>0.05)$. After 8 days of $E$. coli infection, the relative expression of TGF- $\beta 1$ mRNA in only the high-TFCO-dose group was still significantly higher than that of the control group and the positive control (E. coli $+0 \mathrm{mg} / \mathrm{kg}$ TFCO) group $(P<0.05)$ (Table III).

Relationship between duodenal villi histopathology and expression of TGF- $\beta 1 \mathrm{mRNA}$

There was a relationship between the villus length, crypt depth and TGF- $\beta 1$ mRNA expression. The correlation coefficient between TGF- $\beta 1$ mRNA and duodenal crypt depth and duodenal villi length were correlated at 0.9956 and 0.9831 respectively. The corresponding regression formulae were $\mathrm{y}=0.0002 \mathrm{x}-0.0252 \quad\left(\mathrm{R}^{2}=0.9956\right)$ and $\mathrm{y}=0.0003 \mathrm{x}-0.1406\left(\mathrm{R}^{2}=0.9831\right)$. The repair of the villi in the duodenum was also closely related to TGF- $\beta 1 \mathrm{mRNA}$ expression. 
Table III. Effect of Chromolaena odorata Linn. flavonoids on relative expression of TGF- $\beta 1 \mathrm{mRNA}$ in mouse duodenum.

\begin{tabular}{llll}
\hline Groups & \multicolumn{4}{l}{ Number of days following TFCO administration } \\
\hline & $\mathbf{2}$ & $\mathbf{5}$ & $\mathbf{8}$ \\
\hline Control & $0.015 \pm 0.003^{\mathrm{B}}$ & $0.015 \pm 0.004^{\mathrm{B}}$ & $0.016 \pm 0.002^{\mathrm{b}}$ \\
$0 \mathrm{mg} / \mathrm{kg}$ & $0.260 \pm 0.079^{\mathrm{Ab}}$ & $0.173 \pm 0.018^{\mathrm{A}}$ & $0.015 \pm 0.003^{\mathrm{b}}$ \\
$10 \mathrm{mg} / \mathrm{kg}$ & $0.266 \pm 0.011^{\mathrm{Ab}}$ & $0.181 \pm 0.018^{\mathrm{A}}$ & $0.018 \pm 0.002^{\mathrm{ab}}$ \\
$40 \mathrm{mg} / \mathrm{kg}$ & $0.347 \pm 0.135^{\mathrm{Ab}}$ & $0.199 \pm 0.045^{\mathrm{A}}$ & $0.020 \pm 0.004^{\mathrm{ab}}$ \\
$160 \mathrm{mg} / \mathrm{kg}$ & $0.434 \pm 0.030^{\mathrm{Aa}}$ & $0.196 \pm 0.026^{\mathrm{A}}$ & $0.022 \pm 0.003^{\mathrm{a}}$ \\
\hline
\end{tabular}

Compared with the control group, the data in the same column with different lowercase $\left({ }^{\mathrm{a}},{ }^{\mathrm{b}}\right)$ and uppercase letters $\left({ }^{\mathrm{A}},{ }^{\mathrm{B}}\right)$ letters indicate significant differences at $P<0.05$ and $P<0.01$ respectively.

\section{$\operatorname{Ig} M, \operatorname{Ig} A$ and $\operatorname{Ig} G$}

Figure 2 a shows that at day 5 , the $\operatorname{IgM}$ concentrations of mice in the TFCO-treated (Low dose, medium dose, and high dose) groups were significantly higher than in the blank control group $(P<0.05)$, but not between the TFCO treated groups.

At day 5, the $\operatorname{IgA}$ concentrations in the TFCO treatment groups were significantly different from the control group $(P<0.01)$ but not between the treatment groups $(P>0.05)$ (Fig. $2 \mathrm{~b})$. At day 8 , the IgA concentration decreased in the TFCO-treated groups but was still significantly higher than that of the control (saline) group $(P<0.01)$. The high dose $(E$. coli +160 $\mathrm{mg} / \mathrm{kg}$ TFCO) group was significantly higher $(P<0.01)$ than medium dose (E. coli $+40 \mathrm{mg} / \mathrm{kg}$ TFCO) and low dose (E. coli $+10 \mathrm{mg} / \mathrm{kg}$ TFCO) groups.

At 5 days following $E$. coli infection, the $\operatorname{IgG}$ concentrations were significantly $(P<0.05)$ elevated in the treatment groups compared to the control (saline) group (Fig. 2c). Among the treatment groups, the high dose $(E$. coli $+160 \mathrm{mg} / \mathrm{kg}$ TFCO $)$ group was significantly different $(P<0.05)$ from the low TFCO dose $(E$. coli $+10 \mathrm{mg} / \mathrm{kg})$.

At 8 days following $E$. coli infection, the $\operatorname{IgG}$ concentration further increased in all groups with the high dose $(E$. coli $+160 \mathrm{mg} / \mathrm{kg}$ TFCO $)$ group significantly different $(P<0.01)$ from the control (saline) and negative control (E. coli $+0 \mathrm{mg} / \mathrm{kg}$ group) groups. The medium ( $E$. coli $+40 \mathrm{mg} / \mathrm{kg}$ ) and low dose (E. coli $+10 \mathrm{mg} / \mathrm{kg}$ ) groups were also significantly different $(P<0.05)$ from the control (saline) group. Among the TFCO treatment groups, the IgG concentration in the high dose (E. coli $+160 \mathrm{mg} /$ $\mathrm{kg})$ group was significantly different $(P<0.05)$ from the medium TFCO (E. coli $+40 \mathrm{mg} / \mathrm{kg}$ ) and low TFCO (E. coli $+10 \mathrm{mg} / \mathrm{kg}$ ) groups.

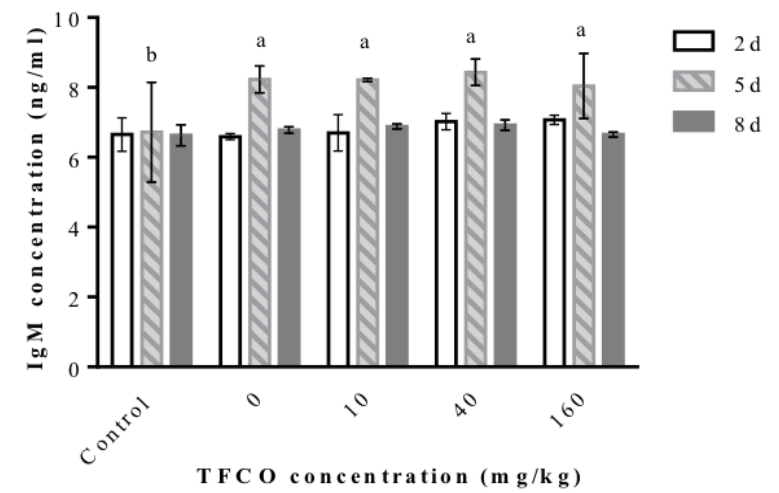

b
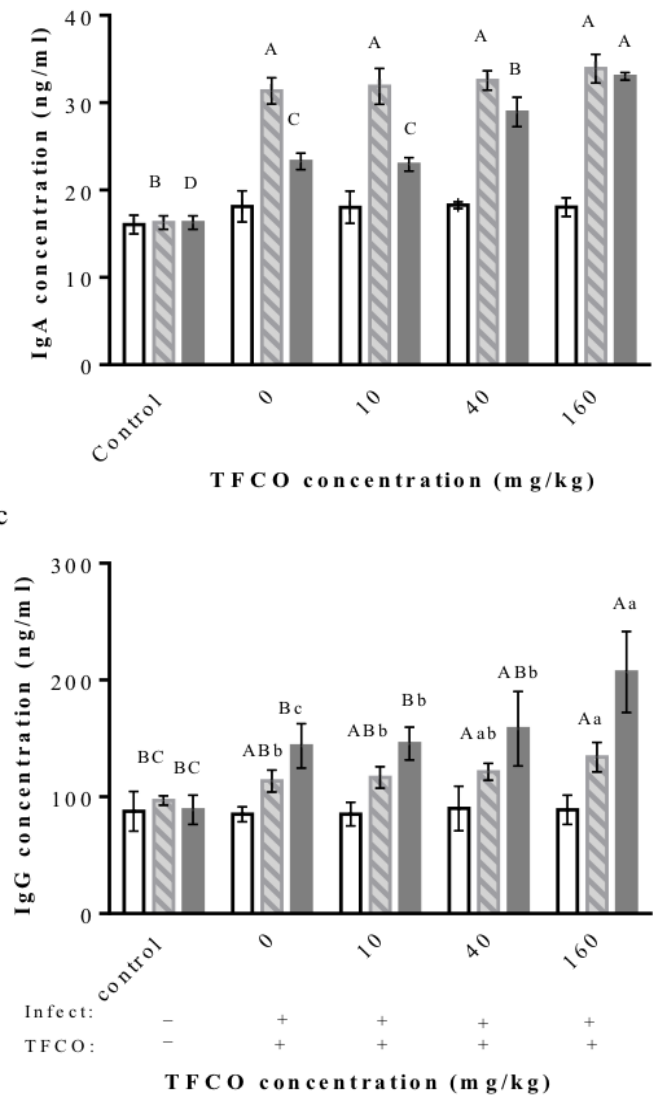

Fig. 2. $\operatorname{IgM}, \operatorname{IgA}$ and $\operatorname{IgG}$ concentrations in control and $E$. coli and Chromolaena odorata Linn. flavonoids (TFCO) exposed mice.

The $0 \mathrm{mg} / \mathrm{kg}$ group is the positive control. The negative sign (-) refers to groups not infected with $E$. coli or treated with TFCO. The positive sign $(+)$ refers to groups infected with $E$. coli or treated with TFCO. Figure $2 \mathrm{a}-\mathrm{c}$ show serum IgM, IgA and IgG concentrations respectively. Compared with the control group, the different lowercase $\left({ }^{\mathrm{a}},{ }^{\mathrm{b}},{ }^{\mathrm{c}}\right)$ and uppercase $\left({ }^{\mathrm{A}},{ }^{\mathrm{B}},{ }^{\mathrm{C}}\right)$ letters indicate significant differences at $P<0.05$, and $P<0.01$ respectively. 


\section{DISCUSSION}

Total flavonoids from C. odorata (TFCO) obtained by ethanol extraction have been identified as kaempferol3-methoxy, rhamnetin, tamarixetin, quercetin, kaempferol, apigenin, luteolin and dihydrokaempferide (Yuan et al., 2007; Zhang et al., 2018). In this study, TFCO was moderately effective against E. coli, Salmonella pullorum, Staphylococcus aureus and Bacillus subtilis in vitro (Luo et al., 2015). In a related study, ethanol extract of $C$. odorata also exhibited inhibitory activity against $S$. aureus (ATCC 29213), E. coli (ATCC 25922) and other gastrointestinal disease-causing bacteria, with MIC values ranging from 0.39 to 3.12 (Omokhua et al., 2017). From this study, the MIC and MBC values of TFCO against $E$. coli were higher than that for $S$. aureus but still regarded as moderately sensitive. E. coli as a gram -negative bacteria and is less inhibited by extracts than gram-positive bacteria such as S. aureus (Palombo and Semple, 2001). The observed higher MIC and MBC values against gram-negative $E$. coli suggests that the TFCO inhibits bacterial growth rather than penetrating into the bacteria cell walls (Omokhua et al., 2017).

In healthy gut, pathogenic bacteria and commensal intestinal tract beneficial bacteria exist in a steadystate (Wang et al., 2017). Upon heavy bacterial such as Escherichia coli (E. coli) infection, the equilibrium is disrupted (Lin et al., 2017). E. coli administered as an intraperitoneally (i.p.) injection may cause intestinal dysbiosis with intestinal mucosal injury, including effects on intestinal villi and intestinal epithelial cell necrosis, which can result in intestinal absorption and secretion dysfunction and may also cause severe diarrhoea and even death (Gomes et al., 2016; Zhang et al., 2017).

Following injury to mucosal epithelial cells in the intestinal tract caused by pathogenic microorganisms (Coddens et al., 2017; Song et al., 2017), the intestinal epithelium undergoes a complex process of wound repair. In this study, i.p injection of TFCO at $160 \mathrm{mg} / \mathrm{kg}$ (high dose) post $E$. coli infection, ameliorated injury in the gut. A molecular study was further conducted to determine the intestinal repair process. TGF- $\beta 1$ is a core factor that contributes to the recovery of injured intestinal epithelial cells (Ando et al., 2007). TGF- $\beta 1$ is a pleiotropic cytokine secreted by immune and non-immune cells in the gut, which plays an important role in promoting the differentiation of regulatory T-cells (Fujio et al., 2016). TGF- $\beta 1$ provides beneficial effects by enhancing the epithelial barrier and providing protection against pathogenic bacteria insults (Howe et al., 2005). It enhances the migration of intestinal epithelial cells, regulate entry and exit to the extracellular matrix, and plays a key role in intestinal tissue remodelling, and thereby accelerate the healing of intestinal injury (Chen et al., 2015). In this study, the relative expression of TGF- $\beta 1 \mathrm{mRNA}$ in the high TFCO $(160 \mathrm{mg} / \mathrm{kg})$ dose group further supports the assertion that TFCO can promote mucosal repair. This was also consistent with the duodenal villi histopathology in the high dose TFCO $(160 \mathrm{mg} /$ $\mathrm{kg}$ ) group. The relationships between the duodenal villi length, the depth of the crypts and the relative expression of TGF- $\beta 1$ mRNA showed a linear correlation for 2, 5 and 8 days in all mice infected with $E$. coli indicating that TFCO can promote the expression of TGF- $\beta 1 \mathrm{mRNA}$, to repair duodenum insult. Degree of intestinal wound repair depends on the extent of damage, adjacent epithelial cell migration, proliferation and differentiation (Tsukahara et al., 2017), and also the influence of a variety of growth factors, such as fibroblast growth factor, epidermal growth factor, and keratinocyte growth factor (Elshaer and Begun, 2017). The ameliorative potentials of $C$. odorata extracts against tissue injuries have demonstrated in-vitro and cell culture studies (Phan et al., 2001; Isirima and Siminialayi, 2018), and the results from this study further supports these assertions. Venous stenosis and tissue disruption in the spleen of Wistar rats infected Salmonella typhi was reversed by $C$. odorata methanol extract at 200 and $400 \mathrm{mg} / \mathrm{kg}$ (Isirima and Siminialayi, 2018). A complex mixture of lipophilic flavonoid aglycones i.e. flavanones, flavonols, flavones and chalcones present in ethanol extract of the plant has potential to protect fibroblasts and keratinocytes (Phan et al., 2001). This is likely due to the inhibition of the bacteria biochemical activities such as release of cytotoxins (Isirima and Siminialayi, 2018). In addition, the flavonoids are antioxidative and can ensure cellular oxidative redox to mitigate cytotoxicity (Phan et al., 2001).

Advances in microbiomics have revealed that gut microbial dynamics changes affect the body's immune factors and functions (Zhang et al., 2018). When mice are infected with $E$. coli, the body's immune system becomes active and releases antibodies and other antigen immunomodulatory substances into the bloodstream. Our results showed that TFCO can improve the antibody titer and enhance serum immunity, as a result of it bacteriostatic effect against $E$. coli. This resulted in the elevated response of the serum $\operatorname{IgA}(P<0.01)$ and $\operatorname{IgG}(P<0.05)$ levels and such effects were most marked in the highest TFCO (E. coli $+160 \mathrm{mg} / \mathrm{kg}$ ) group. This finding agrees with a recent report by Zhang et al. (2018) which reported that, TFCO reduces the population of fermicutes including $E$. coli and enhances serum humoral immunity in broiler chickens. Specific IgGs prevented enteroinvasive $E$. coli induced diarrhoea. Thus, IgG was able to provide effective protection to prevent bacteria-induced diarrhoea (Xu et al., 
2006). This partly accounts for effectiveness of $C$. odorata in the treatments of diarrhoea (Aba et al., 2015).

\section{CONCLUSION}

TFCO exhibited good bacteriostatic effect in vitro and in vivo. It was effective in enhancing antibody release, inducing expression of TGF- $\beta 1 \mathrm{mRNA}$, which can promote the repair of injury to duodenal villi and crypts. This study provides a theoretical basis for exploring the mechanism of the TFCO against E. coli-induced diarrhoea in mice. The study further supports the potential utilization of $C$. odorata as antibacterial agents in food animal productions for biosafety and sustainable livestock productions.

\section{ACKNOWLEDGMENTS}

The study was supported by the Special Competitive Allocation Project (No. 2013A3027) of the Guangdong Province Zhanjiang Programs for Financial Foundation of Science and Technology and Guangdong Postgraduate Education Innovation Project (2020SFJD001).

\section{Statement of conflicts of interest}

The authors have declaredno conflict of interest.

\section{REFERENCES}

Aba, P.E., Joshua, P.E., Ezeonuogu, F.C., Ezeja, M.I., Omoja, V.U. and Umeakuana, P.U., 2015. Possible anti-diarrhoeal potential of ethanol leaf extract of Chromolaena odorata in castor oil-induced rats. $J$. Complement Integr. Med., 12: 301-306. https://doi. org/10.1515/jcim-2014-0033

Alshaikh, N. and Perveen, K., 2017. Anti-candidal activity and chemical composition of essential oil of clove (Syzygium aromaticum). J. Essent. Oil Bear. Pl., 20: 951-958. https://doi.org/10.1080/097 2060X.2017.1375867

Ando, T., Hatsushika, K., Wako, M., Ohba, T., Koyama, K., Ohnuma, Y., Katoh, R., Ogawa, H., Okumura, K., Luo, J., Wyss-Coray, T. and Nakao, A., 2007. Orally administered TGF- $\beta$ is biologically active in the intestinal mucosa and enhances oral tolerance. J. Allergy Clin. Immunol., 120: 916-923. https:// doi.org/10.1016/j.jaci.2007.05.023

Asomugha, R.N., Ezejiofor, A.N., Okafor, P.N. and Ijeh, I.I., 2015. Acute and cytotoxicity studies of aqueous and ethanolic leaf extracts of Chromolaena odorata. Pak. J. biol. Sci., 18: 46-49. https://doi. org/10.3923/pjbs.2015.46.49

Börjesson, S., Guillard, T., Landén, A., Bengtsson, B. and Nilsson, O., 2016. Introduction of quinolone Resistant Escherichia coli to Swedish broiler population by imported breeding animals. Vet. Microbiol., 194: 74-78. https://doi.org/10.1016/j. vetmic.2015.11.004

Bryan, A., Youngste,r L. and Mcadam, A., 2015. Shiga Toxin Producing Escherichia coli. Clin. Lab. Med., 35: 247-272. https://doi.org/10.1016/j. cll.2015.02.004

Chen, T.T., Zheng, F.P., Tao, J., Tan, S.W., Zeng, L.X., Peng, X.J. and Wu, B., 2015. Insulin-Like Growth Factor-1 contributes to mucosal repair by $\beta$-Arrestin 2-mediated extracellular signal-related kinase signaling in experimental colitis. Am. J. Pathol., 185: 2441-2453. https://doi.org/10.1016/j. ajpath.2015.05.020

Clinical and Laboratory Standards Institute., 2017. Methods for dilution antimicrobial susceptibility tests for bacteria that grow aerobically. Approved Guideline M100-A10 CLSI, Wayne, Pennsylvania, USA.

Coddens, A., Loos, M., Vanrompay, D., Remon, J.P. and Cox, E., 2017. Cranberry extract inhibits in vitro adhesion of F4 and F18+ Escherichia coli to pig intestinal epithelium and reduces in vivo excretion of pigs orally challenged with F18+ verotoxigenic E. coli. Vet. Microbiol., 202: 64-71. https://doi. org/10.1016/j.vetmic.2017.01.019

Elshaer, D. and Begun, J., 2017. The role of barrier function, autophagy, and cytokines inaintaining intestinal homeostasis. Semin. Cell Dev. Biol., 61: 51-59. https://doi.org/10.1016/j. semcdb.2016.08.018

Fujio, K., Komai, T., Inoue, M., Morita, K., Okamura, T. and Yamamoto, K., 2016. Revisiting theregulatory roles of the TGF- $\beta$ family of cytokines. Autoimmun Rev., 15: 917-922. https://doi.org/10.1016/j. autrev.2016.07.007

Gomes, T.A. T., Elias, W.P., Scaletsky, I.C.A., Guth, B.E.C., Rodrigues, J.F., Piazza, RMF., Ferreira, L.C.S. and Martinez, M.B., 2016. diarrhoea genic Escherichia coli. Braz J. Microbiol., 47: 3-30. https://doi.org/10.1016/j.bjm.2016.10.015

Howe, K.L., Reardon, C., Wand, A., Nazli, A. and AcKay, D.M., 2005. Transforming growth factor $\beta$ regulation of epithelial tight junction proteins enhances barrier function and blocks enterohemorrhagic Escherichia coli O157: H7induced increased permeability. Am. J. Pathol., 167: 1587-1597. https://doi.org/10.1016/S00029440(10)61243-6

Isirima1, J.C., Siminialayi, I.M., 2018. Effect of 
Chromolaena odorata extract on hematotoxicity and spleen histopathology induced by Salmonella typhi in Wistar rats. Pharmacol. Phar., 9: 85-99. https:// doi.org/10.4236/pp.2018.94007

Lin, D.C., Chen, K.C. and Xie, M.M., 2017. Effect of ceftiofur and enrofloxacin on E. coli sub-population in pig gastrointestinal tract. J. Glob. Antimicrob. Res., 10: 126-130. https://doi.org/10.1016/j. jgar.2017.05.010

Liu, H.W., Tong, J.M. and Zhou, D.W., 2011. Utilization of Chinese herbal feed additives in animal production. Agric. Sci. China, 10: 1262-1272. https://doi.org/10.1016/S1671-2927(11)60118-1

Li, H.Y., Hu, J., Ma, L., Yuan, Z.Y., Wang, Y.G., Wang, X.K., Xing, D.M., Lei, F. and Du, L.J., 2010. Comprehensive study of baicalin down-regulating NOD2 receptor expression of neurons with oxygenglucose deprivation in vitro and cerebral ischemiareperfusion in vivo. Eur. J. Pharmacol., 649: 92-99. https://doi.org/10.1016/j.ejphar.2010.09.023

Luo, B., Guo, M., Niu, J.J., Pei, Q.J., Wang, J.M., Wang, Z.D. and Wang, J.H., 2015. The inhibitory effect of different extraction method of 5 Chinese herbal medicines on Escherichia coli and Staphylococcus aureus (in Chinese). Heilongjiang Anim. Sci. Vet. Med., 4: 164-167.

Ogbonnia, S.O, Mbaka, G.O., Anyika, E.N., Osegbo, O.M. and Lgbokwe, N.H., 2010. Evaluation of acute toxicity in mice and subchronic toxicity of hydroethanolic extract of Chromolaena odorata (L.) King and Robinson (Fam. Asteraceae) in rats. Agric. Biol. J. N. Am., 1: 859-865. https://doi.org/10.5251/ abjna.2010.1.5.859.865

Omokhua, A.G., McGaw, L.J., Chukwujekwu, J.C., Finnie, J.F. and van Staden, J. A., 2017. Comparison of the antimicrobial activity and in vitro toxicity of a medicinally useful biotype of invasive Chromolaena odorata (Asteraceae) with a biotype not used in traditional medicine. S. Afr. J. Bot., 108: 200-208. https://doi.org/10.1016/j.sajb.2016.10.017

Owoyele, B.V., Oguntoye, S.O., Dare, K., Ogunbiyi, B.A, Aruboula, E.A and Soladoye, A.O., 2008. Analgesic, anti-inflammatory and antipyretic activities from flavonoid fractions of Chromolaena odorata. J. med. Pl. Res., 2: 219-225.

Palombo, E.A. and Semple, S.J., 2001. Antibacterial activity of traditional Australian medicinal plants. J. Ethnopharmacol., 77:151-157. https://doi. org/10.1016/S0378-8741(01)00290-2

Panda, D., Dash, S.K. and Dash, G.K., 2010. Qualitative phytochemical analysis and Investigation of anthelmintic and wound healing potentials of various extracts of Chromolaena odorata linn. collected from the locality of Mohuda village, Berhampur (South Orissa). Int. J. Pharm. Sci. Rev. Res., 1: 122126.

Phan, T.T., Wang, L., See, P., Grayer, R.J., Chan, S.Y. and LEE, S.T., 2001. Phenolic compounds of Chromolaena odorata protects cultured skin cells from oxidative damage. Implication for cutaneous wound healing. Biol. Pharma. Bull., 24: 1373-1379 https://doi.org/10.1248/bpb.24.1373

Pisutthanan, N., Liawruangrath B., Liawruangrath, S. and Bremner, J.B., 2006. A new flavonoid from Chromolaena odorata. Nat. Prod. Res., 20: 11921198. https://doi.org/10.1080/14786410600899050

Song, B.C., Li, H.X., Wu, Y.Y., Zhen, W.R., Wang, Z., Xia, Z.F. and Guo, Y.M., 2017. Effect of sodium butyrate dietary supplementation on growth performance and intestinal barrier function of broiler chickens infected with necrotic enteritis. Anim. Feed Sci. Tech., 232: 6-15. https://doi.org/10.1016/j. anifeedsci.2017.07.009

Tonzibo, Z.F., Wognin, E., Chalchat, J.C. and N'Guessan, Y.T., 2007. Chemical Investigation of Chromolaena odorata L. King Robinson from Ivory Coast. J. Essent. Oil Bearing Pl., 10: 94-100. https://doi.org /10.1080/0972060X.2007.10643525

Tsukahara, T., Hamouda, N., Utsumi, D., Matsumoto, K., Amagase, K. and Kato, S., 2017. G protein-coupled receptor 35 contributes to mucosal repair in mice via migration of colonic epithelial cells. Pharmacol. Res., 123: 27-39. https://doi.org/10.1016/j. phrs.2017.06.009

Unnikrishnan, M.K., Veerapur, V., Nayak, Y., Mudgal, P.P. and Mathew, G., 2014. Chapter 13: Antidiabetic, antihyperlipidemic and antioxidant effects of the flavonoids. Polyp. Hum. Heal. Dis., 1: 143161. https://doi.org/10.1016/B978-0-12-3984562.00013-X

Wang, X.M., Li, X.B. and Peng, Y., 2017. Impact of Qi-invigorating traditional Chinese medicines on intestinal flora: A basis for rational choice of prebiotics. Chin. J. Nat. Med., 15: 241-254. https:// doi.org/10.1016/S1875-5364(17)30041-9

Xu, L.B., Chen, L., Gao, W. and Du, K.H., 2006. Bovine immune colostrum against 17 strains of diarrhoea bacteria and in vitro and in vivo effects of its specific IgG. Vaccine, 24: 2131-2140. https://doi. org/10.1016/j.vaccine.2005.11.009

Yuan, J.Q., Yang, J.S. and Miao, J.H., 2007. Studies on flavonoids of Eupatorium odoratum L. J. Chin. Med. Mat., 30: 657-660.

Zhang, Q.H., Nie, F.H., Wang, X.N., Lin, H.Y., Wang, 
H.C.R., Gooneratne, R. and Chen, J.J., 2018. Effect of flavonoids from Eupatorium odoratum L. on immunoglobulins and cecal microflora in broilers. Pak. Vet. J., 38: 296-300.

Zhang, D.X., Zhang, Z.H., Huang, C.C., Gao, X, Wang,
Z., Liu, Y.C., Tina, C.L., Hong, W., Niu, S.L. and Liu, M.C., 2017. The phylogenetic group, antimicrobial susceptibility, and virulence genes of Escherichia coli from clinical bovine mastitis. J. Dairy Sci., 101: 572-580. https://doi.org/10.3168/jds.2017-13159 